\title{
Amylase Production by Aspergillus niger and Penicillium Species by Solid-State and Submerged Cultivation Using Two Food Industrial Wastes
}

\author{
J. Mary Sheela $\dagger$, K. Divya and S. Premina \\ Department of Microbiology, Ethiraj College for Women, Chennai, Tamilnadu, India \\ $†$ Corresponding author: J. Mary Sheela; marysheela_j@ethirajcollege.edu.in
}

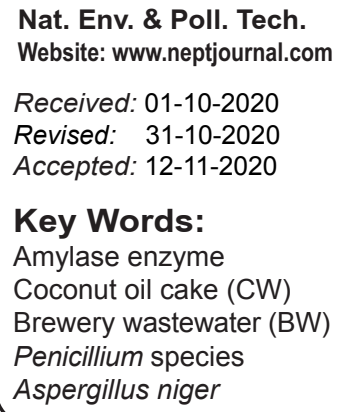

\begin{abstract}
Amylase enzymes are starch degrading enzymes and have received a great deal of attention due to their perceived technology importance and economic benefit. Amylase enzymes are considered important enzymes used in starch processing industries for the hydrolysis of polysaccharides like starch into simple sugar constituents. This enzyme is also involved in the commercial production of glucose. Solid-state cultivation and submerged cultivation have tremendous potentials for enzyme amylase production by using different solid substrates like rice bran, wheat bran, coconut oil cake, and groundnut oil cake which are rich in starch. These agro-industrial wastes are considered cheap raw materials for the production of amylase. Wastewater from the industry like brewery can also be used as a liquid substrate for submerged cultivation. It may have the possibility of depurination of wastewater. In the present study, Aspergillus niger and Penicillium species were isolated and their amylase activity was determined by the starch hydrolysis method. Enzyme production was done by using coconut oil cake as a substrate for solid-state fermentation and brewery wastewater as a substrate for submerged fermentation. The enzyme produced by the organisms was extracted and enzyme assay was done by the Dinitrisalicilic method (DNS method). The protein estimation was done by Lowry Folin's method. The qualitative assay was carried out by performing Gas Chromatography-Mass Spectroscopy (GC-MS).
\end{abstract}

\section{INTRODUCTION}

Enzymes are proteins and consist of long chains of amino acids that fold to produce a three-dimensional structure. Each amino acid sequence produces a specific structure, which has different properties. Enzymes are also responsible for many important biochemical reactions in microorganisms, plants, animals, and human beings. Enzymes differ in their function so that they have the unique ability to facilitate biochemical reactions without undergoing any change themselves. This catalytic ability makes enzymes unique.

Enzymes are biological catalysts with high selectivities. They have been used in the food industry for hundreds of years and play a vital role in many other industries (Detergents, textile manufacturing, pharmaceuticals, pulp, and paper). Recently, enzymes are becoming increasingly important in sustainable technology and green chemistry. They are also produced by various microorganisms including bacterial and fungal species (Esfahanibolandbalaie et al. 2008). Generally, enzymes are active at mild temperatures. Above specific temperature, the enzyme is denaturated. It has characteristic $\mathrm{pH}$ at which their activity is maximum. Extreme $\mathrm{pH}$ values result in electrostatic interactions within the enzyme, leading to the inactivation of enzymes (Prasanna 2005). Other important factors that affect the enzymatic effect are the enzyme concentration, treatment time, additives such as surfactants and chelators, and mechanical stress. The enzyme can break down a particular compound. The molecule that an enzyme acts upon is known as its substrate, which is then converted into a product or products. Some of the most common include amylase which converts starch into simple sugars, proteases that break down proteins, cellulases that break down cellulose, and lipases that split fats into glycerol and fatty acids (Alva et al. 2007). For each type of reaction in a cell, different enzymes are involved and they are broadly classified into six categories such as hydrolytic, oxidizing and reducing, synthesizing, lytic, transferring, and isomerizing. The important characteristic of enzymes is their catalytic function.

Microorganisms particularly have been considered as a treasure of useful enzymes. In recent years, using microorganisms as biotechnological sources of enzymes that are industrially important has stimulated great interest in the exploration of extracellular enzymatic activity in many microorganisms (Pandey et al. 2000). The first industrially produced enzyme was amylase from a fungal source in 1894, which was used for the digestive disorder treatment. Amylases are a class of enzymes that acts as a catalyst in the hydrolysis of starch into simple sugars such as glucose and maltose (Farzana et al. 2016). Amylase is commonly present in human saliva, 
where it begins the chemical process of digestion. Starch degrading enzymes such as amylase have been receiving a great deal of attention and interest due to their perceived technological significance and economic benefits. This enzyme is also used for the industrial production of glucose (Saranraj \& Stella 2013).

Historically, around 1857 the application of enzymes in textile industrial processes began when malt extract was used to remove size from fabrics before the printing process. Starch is widely used as a sizing agent, because it is readily available, relatively cheap, and based on natural, also sustainable raw materials (Adinarayana et al. 2005). About $75 \%$ of the sizing agents used worldwide are starch and its derivatives. In medicinal and clinical areas, there are several processes that involve the application of amylases (Kundu A.K et al. 1970). Because of the increasing demand for these enzymes in various industries, there is more interest in developing enzymes with better and desirable properties such as raw starch degrading amylases that is suitable for industrial applications and their cost-effective production methods (Rodriguez, S.C. and Sanroman, A.M. 2006). They can be obtained from several sources, such as plants, animals, and microorganisms (Saleem et al. 2014).

Amylases are commercially important enzymes and it represents about $25-33 \%$ of the worldwide enzyme market (Mouna Sahnoun et al. 2012). Amylases are of various types, namely $\alpha, \beta$, and glucoamylase. $\alpha$-amylases (endo-1,4- $\alpha$ D-glucan glucohydrolase) are extracellular enzymes that randomly cleaves the 1,4- $\alpha$-D-glycosidic bonds between adjacent glucose units in the linear amylase chain(Sundarram et al. 2014). $\beta$-amylases ( $\beta$-1,4-glucan maltohydrolase) are mostly of plant origin, but some microbial strains are also known to produce them. It is an exoacting enzyme that cleaves amylose at non-reducing ends, amylopectin, and glycogen molecule (Mojsov et al. 2012). Glucoamylase also called amyloglucosidase, gluconeogenic enzymes, starch glucogenase, and exo-1,4- $\alpha$-D-glucan glucanohydrolase. It hydrolyses single glucose units from the non-reducing ends of amylose and also amylopectin in a stepwise manner (Singh et al. 2014).

Although many microorganisms are able to produce this enzyme, some of the most widely used for their industrial applications are Bacillus licheniformis, Bacillus amyloliquefaciens, Aspergillus niger, Penicillium chrysogenum (Saranraj $\&$ Stella 2013). When compared to other microbial sources, the fungal amylases are preferred because of their more acceptable GRAS (Generally Recognized As Safe) status, the conditions such as hyphal mode of growth and good tolerance to low water activity (aw) and high osmotic pressure makes fungal species most efficient for bioconversion of solid substrates and thus attracting more interest as source of amylolytic enzymes suitable for industrial applications as given below (Singh et al. 2014).

\begin{tabular}{|lll|}
\hline $\begin{array}{l}\text { Industrial Appli- } \\
\text { cations }\end{array}$ & Microbial Source & Role \\
\hline $\begin{array}{l}\text { Conversion of } \\
\text { starch }\end{array}$ & $\begin{array}{l}\text { Bacillus } \text { amylolique- } \\
\text { faciens }\end{array}$ & $\begin{array}{l}\text { Liquefaction, } \\
\text { saccharification of } \\
\text { starch. }\end{array}$ \\
Bakery & $\begin{array}{l}\text { Bacillus stearothermo- } \\
\text { philus }\end{array}$ & $\begin{array}{l}\text { Converting starch } \\
\text { into smaller } \\
\text { sugars. }\end{array}$ \\
Betergent & $\begin{array}{l}\text { Bacillus species Asper } \text { - } \\
\text { gillus } \text { species }\end{array}$ & $\begin{array}{l}\text { Degrade the } \\
\text { starchy foods } \\
\text { residues such as po- } \\
\text { tatoes, custard, etc. }\end{array}$ \\
& &
\end{tabular}

Solid-state cultivation is more simple, also requires lower capital, has superior productivity, reduce energy needs, requires simple fermentation media and absence of vigorous control of fermentation parameters, uses less water and produces lower wastewater, has easier control of bacterial contamination, and require a lower cost of downstream processing (Sivaramakrishnan et al. 2007).

Submerged fermentation is advanced and industrially important enzymes are commonly produced by using this method. Brewery industries produce large quantities of wastewater. The utilization of this wastewater as a substrate for submerged fermentation may reduce environmental pollution. Usage of solid substrates like coconut oil cake acts as a low-cost substrate for solid-state fermentation (Mabel et al. 2006).

\section{MATERIALS AND METHODS}

\section{Isolation of Aspergillus niger and Penicillium Species}

Sabouraud Dextrose Agar (SDA) plates were prepared and a settle plate technique was performed. The SDA plates were kept open for 10 mins and incubated at room temperature for 4 days. After incubation, fungal species were observed on SDA medium.

Two different fungal cultures were selected based on their colony morphology and subcultured on SDA slants. These two fungal cultures were subjected to lactophenol cotton blue staining for observing the morphology.

\section{Slide Culture Technique}

A rectangular slab of SDA was prepared and was placed on a clean glass slide. The culture isolate was then inoculated and another glass slide was placed over the top of it to form 
a sandwich. This slide was kept inside a petri dish along with moist cotton and incubated for about 3 days at room temperature. After incubation, the coverslip was placed on a drop of lactophenol cotton blue stain and viewed under the microscope (45x). The morphology of A.niger and P.species were observed and photographed.

\section{Determination of Amylase Activity}

A.niger and P.species isolates were tested for amylase production by starch hydrolysis. Starch agar medium was prepared and inoculated with the isolated organisms and then incubated at room temperature for about 2-3 days. After incubation, the plates were flooded with the iodine solution, and the zone of clearance was observed around the microbial growth, which indicates the production of amylase. Based on the zone of clearance, the fungal isolates were used for further studies on the production of the enzyme amylase.

\section{Enzyme Production}

Enzyme production was done by two methods namely,

- Submerged fermentation (SmF)

- Solid-state fermentation (SSF)

\section{Submerged Fermentation (SmF)}

The inocula were prepared by transferring $2 \mathrm{ml}$ of 60 -hours old culture slant in $50 \mathrm{ml}$ of a medium composed $(\mathrm{g} / \mathrm{L})$ as follows, Glucose-20; (NH4) SO4-6.6; $\mathrm{KH}_{2} \mathrm{PO} 4-3.5$; FeSO4.7H2O-0.15; $\mathrm{MgSO} 4.7 \mathrm{H}_{2} \mathrm{O}-0.10$;

$\mathrm{MnCl}_{2} .2 \mathrm{H} 2 \mathrm{O}-0.45$; Mycological peptone-3.0. The media $\mathrm{pH}$ was adjusted at 6.8 and then autoclaved at $121^{\circ} \mathrm{C}$ for 15 mins. The media was allowed to cool and inoculated. After inoculation, the culture was incubated at $30^{\circ} \mathrm{C}$ for $48 \mathrm{~h}$.

Brewery wastewater, which was used as the culture media base, was collected from the local brewery plant. The brewery wastewater was subjected to centrifugation at $12,000 \mathrm{rpm}$ for 15 mins to remove the solids suspensions. The supernatant was collected for further use. The production media was obtained by supplementing this supernatant with the following nutrients (g/l): Mycological peptone-3.0; (NH4)SO4-6.6; CacO3-8.0; NaCl-5; KH2PO4-3.5; FeSO4.7H2O-0.15; $\mathrm{MgSO} 4.7 \mathrm{H} 2 \mathrm{O}-0.10$; Soluble potato starch-40. The media $\mathrm{pH}$ was adjusted at 6.0 and sterilized $\left(121^{\circ} \mathrm{C}\right.$ for $\left.15 \mathrm{mins}\right)$, inoculated with $2 \%$ inoculum level, and incubated at $30^{\circ} \mathrm{C} .88$ $\mathrm{h}^{-1}$ (Mabel et al. 2006).

\section{Solid-State Fermentation (SSF)}

Substrates like coconut oil cake were used as a solid substrate for solid-state fermentation. Ten $\mathrm{g}$ of coconut oil cake was weighed and hydrated with $10 \mathrm{~mL}$ of basal salt solution and adjusted with moisture content from 43-81\% (Ramachandran et al. 2004). The substrate was sterilized by autoclaving at $12^{\circ} \mathrm{C}$ for 15 mins. $1 \%$ of inoculum was inoculated after sterilization and then incubated at room temperature for 6 days (Suganthi et al. 2011).

\section{Enzyme Extraction for Submerged Culture}

After incubation, the culture sample was filtered by using Whatman filter paper No.1. The paper-filtered media was used to perform analytical determinations (Mabel et al. 2006).

\section{For Solid-state Culture}

After incubation, $0.1 \mathrm{M}$ phosphate buffer saline was prepared and $\mathrm{pH}$ was adjusted to $\mathrm{pH}$ 7.0. $22 \mathrm{~mL}$ of freshly prepared phosphate buffer saline was added to the substrate beds and shaken vigorously in a rotary shaker for $15-20$ mins at $120 \mathrm{rpm}$.

The mixture was then filtered through a cheese cloth and the filtrate was subjected to centrifugation at $8000 \mathrm{rpm}$ at 4 for 15 mins. The supernatant was collected in a clean fresh tube and it was filtered through a cheese cloth, the filtrate was used as the crude enzyme preparation (Suganthi et al. 2011).

\section{Assay of Amylase Activity}

\section{Dinitro Salicylic Acid Method (DNS)}

For standard preparation, different concentration of maltose ( $1 \mathrm{~mm}, 2 \mathrm{~mm}, 3 \mathrm{~mm}, 4 \mathrm{~mm}, 5 \mathrm{~mm}, 10 \mathrm{~mm}$ ) was prepared and DNS assay was performed. 6 tubes were arranged in a row of test tube rack and labeled as $\mathrm{S} 1, \mathrm{~S} 2, \mathrm{~S} 3, \mathrm{~S} 4, \mathrm{~S} 5, \mathrm{~S} 6$, T1 (A.niger BW), T2 (Penicillium sps BW), T3 (A. niger $\mathrm{CW}$ ), T4 (Penicillium sps $\mathrm{CW}$ ). $1 \mathrm{~mL}$ of the respective stocks and samples were transferred to the labeled tubes. $1 \mathrm{~mL}$ of DNS reagent was added to all the tubes, then all the tubes were heated at $100^{\circ}$ for 5 mins. After heating, the tubes were allowed to cool. All the tubes were made into $10 \mathrm{~mL}$ with distilled water. Then it was transferred to cuvettes and the absorbance value was noted at $540 \mathrm{~nm}$ using a calorimeter. The graph was plotted with a concentration of maltose at the $\mathrm{x}$-axis and absorbance value (OD value) at the y-axis.

\section{Estimation of Protein Lowry-Folin's Method}

A series of tubes were taken and labeled as Blank, S1, S2, S3, S4, S5, S6, T1, T2, T3, T4 respectively. $0.5 \mathrm{~mL}, 1 \mathrm{~mL}$, $1.5 \mathrm{~mL}, 2 \mathrm{~mL}, 2.5 \mathrm{~mL}$, and $3 \mathrm{~mL}$ of Bovine serum albumin (standard) was added to the S1, S2, S3, S4, S5, S6 respectively. $1 \mathrm{~mL}$ of samples were added to T1, T2, T3, T4. All the tubes were made up to $3 \mathrm{~mL}$ with distilled water. Then $4.5 \mathrm{~mL}$ of Alkaline copper reagent was added to all the test tubes. $0.5 \mathrm{~mL}$ of Folin's reagent was added to all the test 
tubes and incubated at room temperature for 10 mins. After incubation absorbance value was noted at $560 \mathrm{~nm}$ using a calorimeter. The graph was plotted with a concentration of protein at the $\mathrm{x}$-axis and absorbance value (OD value) at the y-axis.

\section{Gas Chromatography-Mass Spectroscopy (GC- MS)}

The enzyme samples were qualitatively assayed by performing Gas Chromatography-Mass Spectroscopy (GC-MS). GCMS was performed by using equipment 7000 Series Triple Quad GC/MS for the enzyme samples to identify the amount and type of chemicals present in the sample by measuring the mass-to-charge ratio and abundance of gas-phase ions. This equipment is a standalone capillary GC detector for use with the Agilent 7890A Series gas chromatograph. Mass spectroscopy works by the principle of ionizing chemical compounds to generate charged molecules and measuring their mass-to-charge ratio.
In GCMS, the sample is ionized. Molecules of the samples break into a charged fragment during the ionization process. Ions are separated based on their mass-to-charge ratio $(\mathrm{m} / \mathrm{z})$. Ions are detected by using a mechanism that has the ability to detect charged particles (e.g. electron multiplier). Results are finally displayed as spectra of the relative abundance as a function of the $\mathrm{m} / \mathrm{z}$ ratio. Identification is carried out by correlating known masses to the identified masses or by a characteristic fragmentation pattern.

\section{RESULTS AND DISCUSSION}

\section{Isolation of Organisms}

Fungal cultures like P.species and A.niger were isolated by the settle plate technique. The colony morphology on the SDA plate was observed as follows,

- The colonies cottony in texture, initially white and later became gray-green or olive-gray (Fig. 1a).
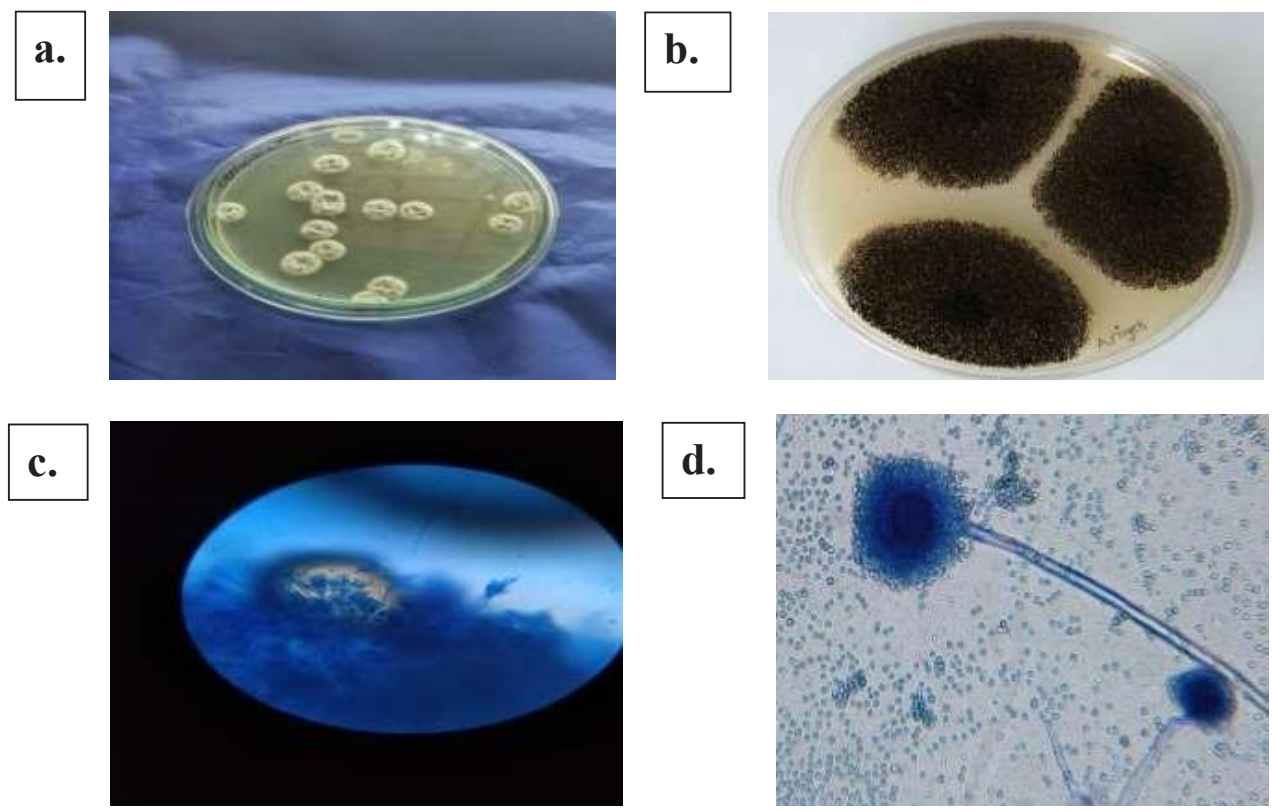

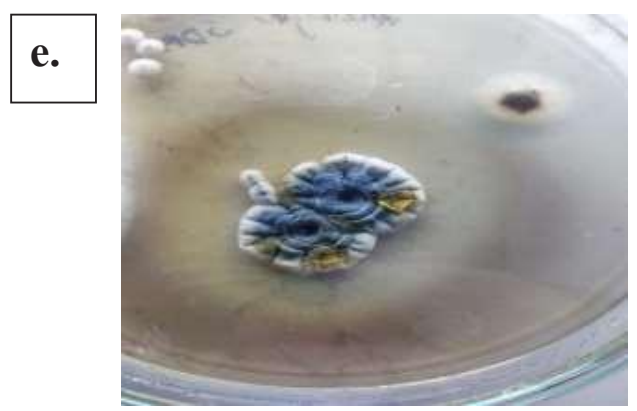

Fig. 1: a. SDA plates showing Penicillium species b. SDA plates showing Aspergillus niger c. Lacto phenol cotton blue staining showing Penicillium species d. Lacto phenol cotton blue staining showing Aspergillus niger e. Plate showing zone of clearance around Penicillium species colonies. 
- Salt and pepper appearance and reverse turning pale yellow (Fig. 1b).

\section{Slide Culture Technique}

The morphology was microscopically observed by performing slide culture technique and the structure was identified by staining with lactophenol cotton blue stain as follows,

- Dense, brush-like, spore-bearing structures. Simple or branched conidiophores and terminated by flask-shaped phialides. It confirms P.species (Fig. 1c).

- Dark brown in color, globose vesicle with primary and secondary sterigmata, and conidiospores cover the entire surface of the conidial head. It confirms A.niger (Fig. 1d).

\section{Determination of Amylase Activity}

A starch hydrolysis test was performed. Zone of clearance
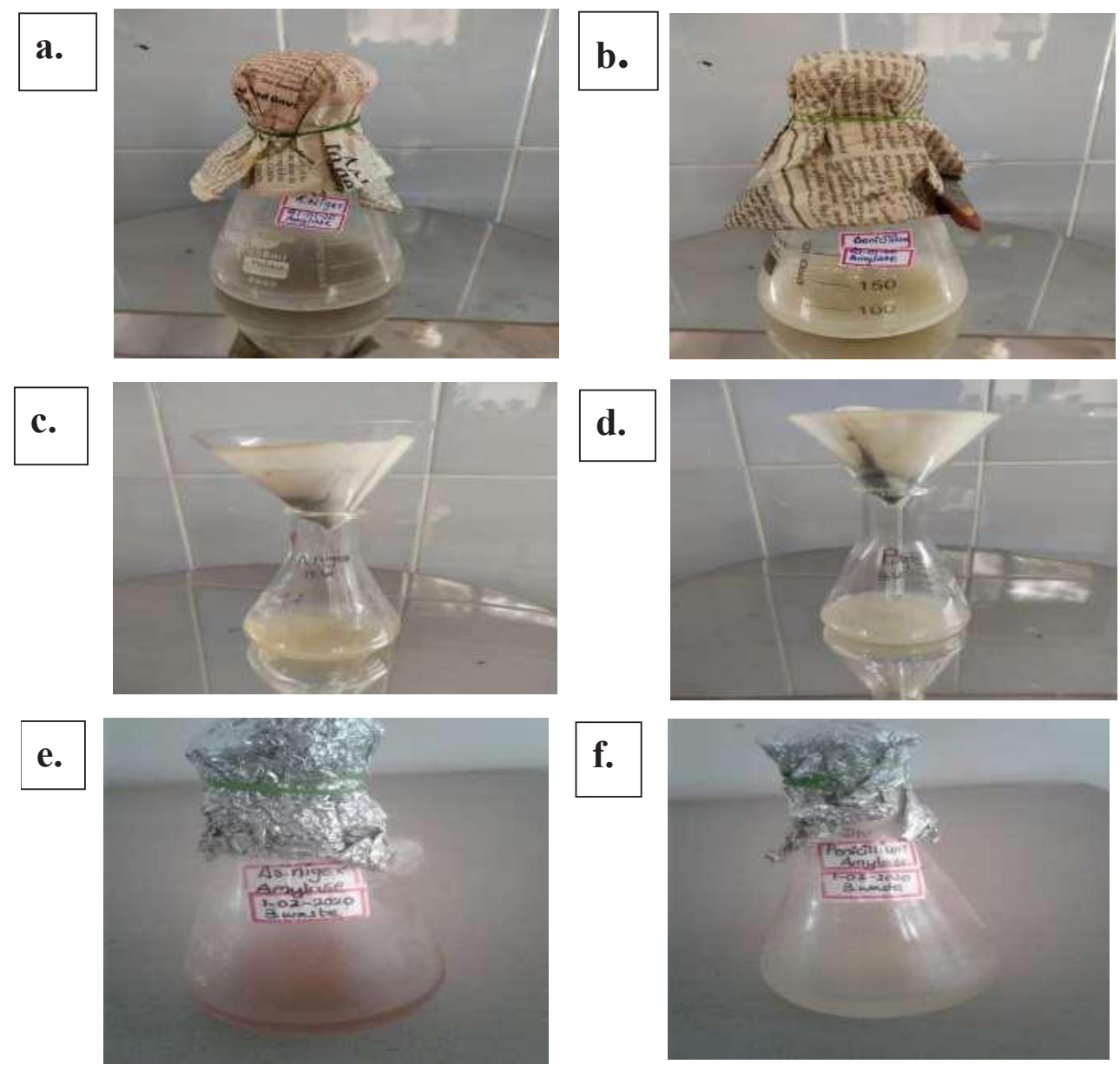

was observed around the colonies on each plate containing A.niger and P.species (Fig.1e). It indicates the ability of the isolated organisms to produce the enzyme amylase.

\section{Submerged Fermentation}

The brewery wastewater supplemented with nutrients was used as a liquid medium. A.niger and P.species were inoculated in two different conical flasks containing liquid medium and incubated (Fig. 2a, 2b).

After incubation, the culture medium was paper filtered (Fig. 2c, 2d). The filtrate was used as a crude enzyme (Fig. $2 \mathrm{e}, 2 \mathrm{f})$.

\section{Solid-State Fermentation}

Coconut oil cake was used as a solid substrate. The substrate was inoculated with A.niger and P.species in two different conical flasks and incubated. 
After incubation, the mat growth was observed (Fig. 3a, 3b). It was then centrifuged and the supernatant (Fig. 3c, $3 d$ ) was filtered using a cheese cloth and used as a crude enzyme (Fig. 3e, 3f).

\section{Assay of Amylase Activity Dinitrosalicyclic Acid Method}

Dinitrosalicylic method was performed. The absorbance value was noted at $540 \mathrm{~nm}$ using a calorimeter for enzyme samples and standards (Fig. 4b). The graph was plotted with a concentration of maltose against absorbance (OD value) (Fig. 4a). From the graph, the concentration of amylase in the enzyme samples was determined (Fig. 4c).

\section{Estimation of Protein by Lowry Folin's Method}

The protein content of the samples was estimated using Lowry Folin's method. The absorbance value for the standards and test were noted at $560 \mathrm{~nm}$ using a calorimeter (Fig. $5 b)$. The graph was plotted with concentration along the $\mathrm{x}$-axis against absorbance value along the $\mathrm{y}$-axis (Fig. 5a). The concentration of protein of crude enzyme extracts was estimated (Fig. 5c).

\section{Gas Chromatography-Mass Spectroscopy}

GC-MS was performed for the enzyme samples for qualitative analysis. Various chemi-
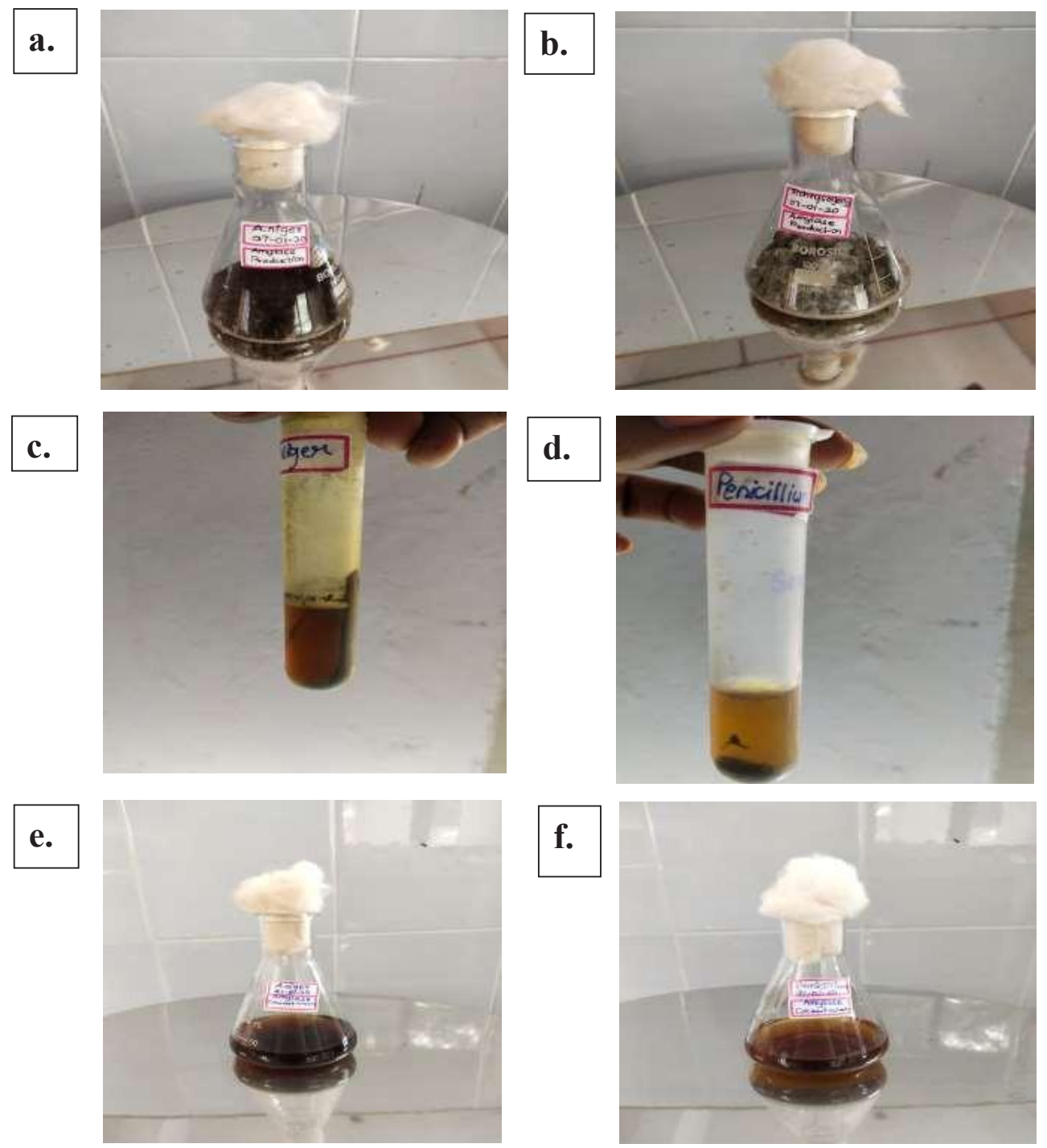

Fig. 3: a. Solid-State fermentation(SSF) of Aspergillus niger b. Solid-State fermentation of Penicillium species c. Supernatant obtained from centrifugation of filtrate from SSF of Aspergillus niger d. Supernatant obtained from centrifugation of filtrate from SSF of Penicillium species e. Crude enzyme obtained from SSF of Aspergillus niger f. Crude enzyme obtained from SSF of Penicillium species 


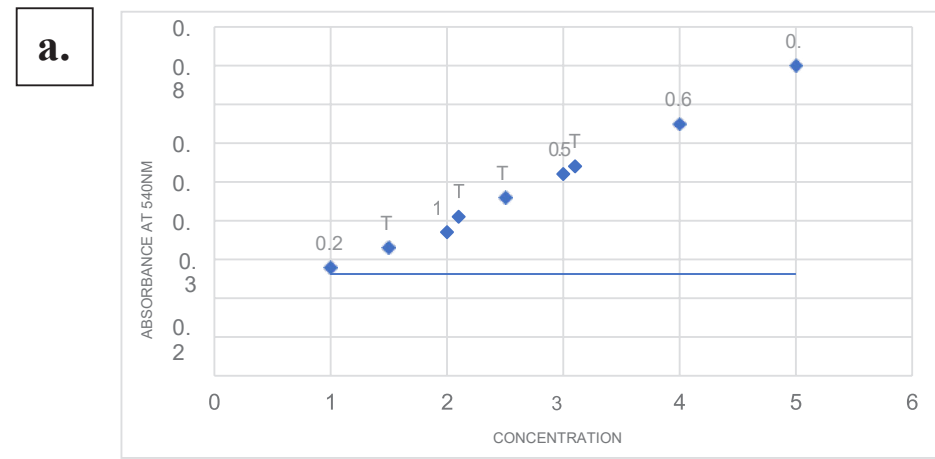

\begin{tabular}{|r|r|c|c|}
\hline b. & CONCENTRATION & $\begin{array}{c}\text { ABSORBANCE } \\
\text { (nm) }\end{array}$ \\
\cline { 2 - 4 } & & $1 \mathrm{~mm}$ & 0.31 \\
\hline $\mathrm{S} 1$ & $2 \mathrm{~mm}$ & 0.35 \\
\hline $\mathrm{S} 2$ & $3 \mathrm{~mm}$ & 0.40 \\
\hline $\mathrm{S} 3$ & $4 \mathrm{~mm}$ & 0.65 \\
\hline $\mathrm{S} 4$ & $5 \mathrm{~mm}$ & 0.80 \\
\hline $\mathrm{S} 5$ & - & 0.33 \\
\hline $\mathrm{T} 1$ & - & 0.26 \\
\hline $\mathrm{T} 2$ & - & 0.50 \\
\hline $\mathrm{T} 3$ & - & 0.41 \\
\hline $\mathrm{T} 4$ & &
\end{tabular}

\begin{tabular}{|c|c|}
\hline c. & $\begin{array}{c}\text { TEST } \\
\text { SAMPLES } \\
\left(\mathrm{mg}^{\left.-\mathrm{mL}^{-1}\right)}\right.\end{array}$ \\
\hline $\mathrm{T} 1$ & 2 \\
\hline $\mathrm{T} 2$ & 1.5 \\
\hline $\mathrm{T} 3$ & 3.1 \\
\hline $\mathrm{T} 4$ & 2.5 \\
\hline
\end{tabular}

Fig. 4: a. Graph plotted with concentration against absorbance b. Absorbance value of standards and samples in DNS method c. Concentration of amylase in test samples.

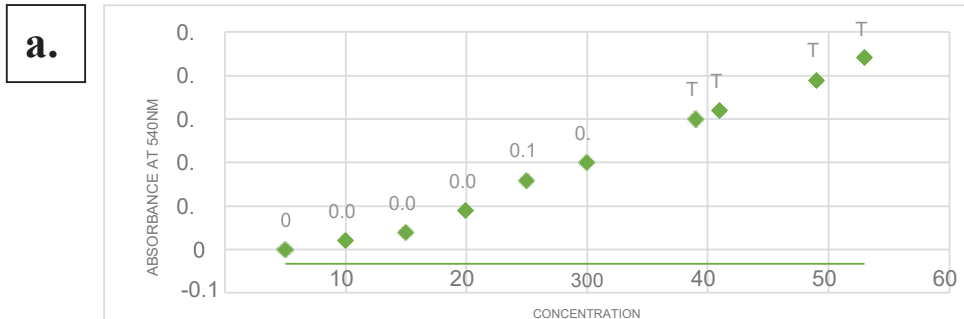

\begin{tabular}{|c|c|c|c|}
\hline $\mathbf{b}$ & $\begin{array}{c}\text { CONCENTRATION } \\
(\mathrm{mL})\end{array}$ & $\begin{array}{c}\text { ABSORBANCE } \\
(\mathrm{nm})\end{array}$ \\
\cline { 2 - 4 } & S1 & 50 & 0 \\
\hline S2 & 100 & 0.02 \\
\hline S3 & 150 & 0.04 \\
\hline S4 & 200 & 0.09 \\
\hline S5 & 250 & 0.16 \\
\hline S6 & 300 & 0.2 \\
\hline T1 & - & 0.32 \\
\hline T2 & - & 0.30 \\
\hline T3 & - & 0.44 \\
\hline T4 & - & 0.39 \\
\hline
\end{tabular}

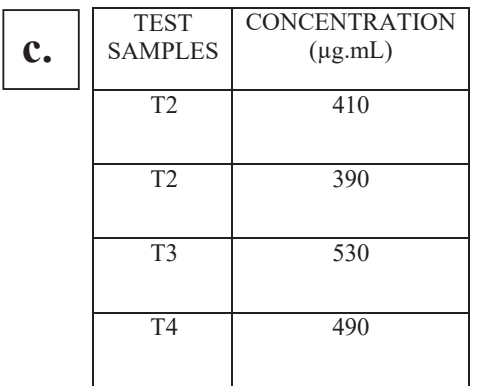

Fig. 5: a. Graph plotted with concentration against absorbance b. Absorbance values obtained from Lowry Folin's method c. Concentration of protein in crude enzymes by Lowry Folin's method. 
cal compounds for each test sample were observed (Tables 1, 2, 3 and 4).

\section{DISCUSSION}

Amylase is a vital enzyme involved not only in modern biotechnology but also employed in various industries like starch processing industries for the hydrolysis of polysaccharide and paper industries. Enzyme amylase obtained from fungal species has large applications in the food and pharmaceutical industries and also widely used for the preparation of oriental foods.

The present study states that the enzyme amylase can be produced by using food wastes like brewery wastewater and coconut oil cake that are cost-effective and easily available when compared to the conventional substrates. Using brewery wastewater as a substrate may also reduce environmental pollution. A.niger and P.species were isolated by using the settle-plate technique. The slide culture technique was carried out to observe the morphology of the organisms.

Starch hydrolysis test was performed, zone of clearance around the colonies indicates their ability to produce the enzyme amylase. Enzyme production was done by submerged cultivation using brewery wastewater as a liquid substrate, and solid-state fermentation using coconut oil cake as a solid substrate. Crude enzymes were obtained by using the

Table 1: GC-MS analysis of the crude extract from SSF of Penicillium species.

\begin{tabular}{|lllll|}
\hline S. No. & Compound Name & Structural Formula & $\begin{array}{l}\text { Molecular Weight } \\
\left(\mathrm{g} \cdot \mathrm{mol}^{-1}\right)\end{array}$ & $\begin{array}{l}\text { Retention } \\
\text { Time }\end{array}$ \\
\hline 1 & $\begin{array}{l}\text { Naphtho[1,2-b]furan2- one,2,3,3a,4,5,5a,6,7,9a,9 } \\
\text { b-decahydro-3,5a,9- trimethyl-7,9a-peroxy }\end{array}$ & $\mathrm{C} 15 \mathrm{H} 20 \mathrm{O} 4$ & 262.17 & 12.864 \\
2 & $\begin{array}{l}\text { 7,9-Di-tert-butyl-1- oxaspiro(4,5)deca6,9- di- } \\
\text { ene-2,8-dione }\end{array}$ & $\mathrm{C} 17 \mathrm{H} 24 \mathrm{O} 3$ & 276.36 & 18.899 \\
3 & 2-Oxepanone,5-(1,1- dimethylethyl) & $\mathrm{C} 10 \mathrm{H} 18 \mathrm{O} 2$ & 170.24 & 29.022 \\
\hline
\end{tabular}

Table 2: Qualitative analysis of the crude extract from SSF of Aspergillus niger.

\begin{tabular}{|lllll|}
\hline S. No. & Compound Name & Structural Formula & $\begin{array}{l}\text { Molecular Weight } \\
\left(\mathrm{g} \cdot \mathrm{mol}^{-1}\right)\end{array}$ & Retention Time \\
\hline 1 & Dodecanal & $\mathrm{C} 12 \mathrm{H} 24 \mathrm{O}$ & 184.3 & 8.724 \\
2 & $\begin{array}{l}\text { Phthalic acid, butyl } \\
\text { cyclobutyl ester }\end{array}$ & $\mathrm{C} 16 \mathrm{H} 20 \mathrm{O} 4$ & 276.32 & 18.891 \\
3 & $\begin{array}{l}\text { Bis(2-ethylhexyl) } \\
\text { phthalate }\end{array}$ & $\mathrm{C} 24 \mathrm{H} 38 \mathrm{O} 4$ & 390.55 & 29.010 \\
\hline
\end{tabular}

Table 3: Qualitative analysis of the crude extract from SmF of Penicillium species.

\begin{tabular}{|lllll|}
\hline S. No. & $\begin{array}{l}\text { Compound } \\
\text { Name }\end{array}$ & Structural Formula & $\begin{array}{l}\text { Molecular Weight } \\
\left(\mathrm{g} \cdot \mathrm{mol}^{-1}\right)\end{array}$ & Retention Time \\
\hline 1 & Benzothiazole,2-(2- hydroxyethylthio)- & C9H9NOS2 & 211.30 & 19.862 \\
2 & 1,4-Benzenediamine, N-(1,3- dimethylbutyl)-N'- phenyl & C18H24N2 & 268.39 & 29.002 \\
3 & 1,3Benzenedicarboxylic acid,bis(2-ethylhexyl) ester & C24H38O4 & 390.55 & 37.291 \\
\hline
\end{tabular}

Table 4: Qualitative analysis of the crude extract from SmF of Aspergillus niger.

\begin{tabular}{|lllll|}
\hline S. No. & Compound Name & Structural Formula & $\begin{array}{l}\text { Molecular Weight } \\
\left(\mathrm{g} \cdot \mathrm{mol}^{-1}\right)\end{array}$ & Retention Time \\
\hline 1 & Z-8-Methyl-9- tetradecenoic acid & $\mathrm{C}_{15} \mathrm{H}_{28} \mathrm{O}_{2}$ & 240.38 & 9.691 \\
2 & 7,9-Di-tert-butyl-1- oxaspiro(4,5)deca-6,9- diene2,8dione & $\mathrm{C}_{17} \mathrm{H}_{24 \mathrm{O}}$ & 276.36 & 18.891 \\
3 & cis-13-Octadecenoic acid & $\mathrm{C}_{18} \mathrm{H}_{34} \mathrm{O}_{2}$ & 282.46 & 29.023 \\
\hline
\end{tabular}


performed. Qualitative analysis of enzyme extract was done by performing Gas Chromatography-Mass Spectroscopy (GC-MS).

\section{CONCLUSION}

Amylase enzyme was produced by using food industrial wastes such as coconut oil cake as a solid substrate for solid-state fermentation and brewery wastewater as a liquid substrate for submerged fermentation. It indicates that the utilization of these wastes as a substrate may decrease environmental pollution and also reduces the production cost of the enzyme amylase.

\section{REFERENCES}

Adinarayana, K., Kugan, P. and Suren, S. 2005. Amylase production in solid-state fermentation by the Thermophilic lanuginosus. J. Biosci. Bioeng., 100(2): 168-171.

Alva, S., Anupama, J., Savla, J., Chiu, Y.Y., Vyshali, P., Sruthi, M., Yogeetha, B.S., Bhavya, D., Purvi, J., Ruchi, K., Kumudini, B. S. and Varalakshmi, K.N. 2007. Production and characterization of fungal amylase enzyme isolated from Aspergillus species. JGI 12 in solid-state culture. Afr. J. Biotechnol., 6(5): 576-581.

Esfahanibolandbalaie, Z., Rostami, K. and Mirdamadi, S.S. 2008. Some studies of $\alpha$-Amylase production using Aspergillus oryzae. Pak. J. Biol. Sci., 11(22): 2553-2559.

Farzana,Y., Minhal, A., Amna, A., Hafsa, S., Azra, N., Asma, A., Shakeel, A.K. and Shah, A.U.Q. Solid state fermentation: A cost-effective approach for the production of starch liquefying fungal amylase using agro-industrial wastes. Sci. Int., 28(3): 2703-2706.
Kundu, A.K. and Das, S. 1970. Production of amylase in liquid culture by strains of Aspergillus oryzae. Amer. Soc. Microbiol., 19(4): 598-603.

Mabel. S.H., Marilu, R., Ne, 1.P.G. and Renato, P.R..2006. Amylase production by Aspergillus niger in submerged cultivation on two wastes from food industries. J. Food Eng., 73: 93-100.

Mojsov, K. 2012. Microbial $\alpha$-amylases and their industrial applications: A review. Int. J. Manag., 2(10): 583-609.

Naidu, M.A. and Saranraj, P. 2013. Bacterialamylase: A review. Int. J. Pharm. Biol. Arch., 4(2): 274-287.

Prasanna, V.A.. 2005. Amylase and their applications. Afr. J. Biotechnol., 4(13): 1525-1529.

Ramachandran, S., Patel, A.K., Nampoothiri, M., Francis, F., Nagy, V., Szakacs, G. and Pandey, A. 2004. Coconut oil cake: A potential raw material for the production of $\alpha$ - amylase. Biosource Technol., 93: 169-174.

Rodriguez, S.C. and Sanroman, A.M. 2006. Application of solid-state fermentation to the food industry. J. Food Microbiol., 76: 291-302.

Saranraj, P. and Stella, D. 2013. Fungal amylase: A review. Int. J. Microbiol. Res., 4(2): 203-211.

Saleem, A., Mohsen, K.H. and Ebrahim, E. 2014. Production of amylase by fungi isolated from legume seeds collected in Almadinah Almunawwarah, Saudi Arabia. J. Taibah Univ. Sci., 8: 90-97.

Singh, S., Singh, S., Bali, V., Sharma, L. and Mangla, J. 2014. Production of fungal amylases using cheap, readily available agriresidues, for potential application in textile industry. Biomed Res. Int.., 2014(8): 1-9.

Sivaramakrishnan, S., Gangadharan, D., Nampoothiri, K.M., Soccol, C.R. and Pandey, A. 2007. Alpha-amylase production by Aspergillus oryzae employing solid-state fermentation. J. Sci. Ind. Res., 66(8): 621-626. Sundarram, A. and Thirupathihali, P.K.M. 2014. Alpha-amylase production and application: A review. J. Appl. Environ. Microbiol., 2(4): 166-175.

Suganthi, R., Benazir, J.F., Santhi, R., Ramesh Kumar, V., Anjana, H., Nitya, M., Nidhiya, K.A., Kavitha, G. and Lakshmi, R. 2011. Amylase production by Aspergillus niger under solid-state fermentation using agroindustrial wastes. Int. J. Eng. Sci. Technol., 3(2): 1756-1763. 